\title{
“EGRESSAS” DE SERVIÇOS DE ACOLHIMENTO E A INVENÇÃO DE NOVAS POSSIBILIDADES DE VIDA
}

\section{Fernanda Cruz Rifiotis}

(D) https://orcid.org/0000-0002-7307-2254

Pós-doutoranda no Programa de Pós-Graduaçăo em Antropologia Social da Universidade Federal do Rio Grande do Sul (UFRGS). E-mail: frifiotis@gmail.com.

DOI: $10.1590 / 349914 / 2019$

\section{Introdução}

O desacolhimento da Nina sempre foi um caso complicado para a direção e os profissionais que trabalhavam na casa-lar. Antes mesmo de completar dezoito anos, ela não tinha nenhum parente ou amigo que a pudesse acolher. Esgotadas as possibilidades de retorno familiar, a instituição começou a investir na autonomia da jovem (através da realização de cursos e estágios) para que ela trabalhasse e tivesse alguma renda para se manter de maneira independente ao deixar a casa-lar. O desacolhimento mostrou para a jovem que, no lugar da preparação, ela teria que assumir o curso da sua própria vida, ou, como ela diz: "É aquele ditado, a dor ensina a gemer", e completa: "eles mandavam a gente fazer curso, diziam que era nosso preparatório para sair, mas um curso não te prepara para a vida aqui fora. $\mathrm{Na}$ verdade, ninguém sai preparado de lá, a gente aprende na marra. $\mathrm{Na}$ época em que eu saí do abrigo, eu não estava mais na Caixa Econômica Federal. E que preparação é essa? Se eu não tinha nenhum emprego e eu tinha que me mudar. Eu ia sair só com 5 mil que eu tinha juntado na Caixa, que eu não gastava, juntava tudo para sair, para me sustentar até conseguir um empreguinho".

E conclui:

"É como se tu tá num internato e é cuidado por um bando de gente que acha que as coisas são melhores para ti, tentam fazer tu te sentir melhor, e não é melhor. Tu sabe que lá não é a tua família e tu tem que aguentar, porque tu 
não tem outra escolha, até o dia que tu tem que sair e enfrentar aqui fora". ${ }^{1}$

Preparação para a saída, tensão permanente entre as demandas dos sujeitos e as expectativas das políticas de proteção, chegada da maioridade, autonomia, vida fora do abrigo e retorno para a família são questóes correntes quando se trata de pensar a desinstitucionalização de jovens que passaram a infância e/ ou a adolescência em serviços de acolhimento institucional $^{2}$ (abrigos e casas-lares). Foram relatos como os da Nina que me inspiraram a realizar a minha tese de doutorado (Cruz, 2014) sobre as experiências de desinstitucionalização de oito ${ }^{3}$ jovens de Santa Catarina (Florianópolis e Palhoça) e do Rio Grande do Sul (Porto Alegre), "egressas" desses serviços de acolhimento. O presente artigo é, portanto, fruto dessa pesquisa, que já deu origem a outros textos, nos quais o material etnográfico foi parcialmente compartilhado, apresentando, contudo, análises e objetivos diferentes.

Durante a realização da etnografia, entre 2010 e 2013, foi possível perceber que, no Brasil, há muitos pesquisadores interessados nos espaços das instituiçóes; porém, a reflexão acerca dos "egressos" é muito tímida, tanto por parte dos pesquisadores como por parte do governo e das entidades assistenciais. Foi somente nos anos de 1980 que a busca por alternativas às práticas de institucionalização ganhou visibilidade no país. A partir dessa época foram intensificados os questionamentos e até mesmo o repúdio às práticas de abrigamento, tendo como base diversos estudos que sinalizavam as consequências da institucionalização sobre o desenvolvimento das crianças e dos adolescentes. Tanto que o "maior destaque" da década de 1990 foi para o processo de discussão e redação do Estatuto da Criança e do Adolescente (ECA), que substituiu a segunda versão do Código de Menores (1979) e marcou a passagem de uma concepção do menor como objeto de medidas judiciais para outra, que reconhece as crianças e os adolescentes como sujeitos de direitos (Rizzini e Rizzini, 2004).

Até então, como observa Altoé (2009), a questão do desligamento institucional também não chamava a atenção, e esse processo "parecia" transcorrer sem maiores problemas. Foi somente devido às denúncias feitas nos jornais pela Associação dos Ex-Alunos da Funabem (Asseaf), sobre o abandono em que se encontravam os adolescentes que deixavam a Fundação Nacional de Bem-Estar do Menor (Funabem), que essa situação se tornou "um problema conhecido". Com a implementação do ECA observou-se uma mudança na característica dos abrigos, sobretudo no que se refere à concepção de confinamento. Entretanto, a premissa da provisoriedade vem sendo sistematicamente ignorada, pois "faltam alternativas efetivas de atendimento que permitam reverter as situaçóes que levaram ao acolhimento, dentro do tempo previsto pela legislação" (Rizzini e Rizzini, 2007, p. 91).

Os poucos trabalhos pós-ECA (anos de 1990) sobre essa temática no país ainda permanecem centrados e balizados por elementos institucionais e pelas consequências da institucionalização sobre a trajetória dos jovens (Figueiró, 2012). Entre os poucos trabalhos antropológicos mais recentes, estão os desenvolvidos pela equipe de pesquisadores do Núcleo de Antropologia e Cidadania da Universidade Federal do Rio Grande do Sul (Naci/ UFRGS) (Fonseca, Allembrandt e Ahlert, 2009; Fonseca, Magni, Pasini e Paim, 2009), os quais me forneceram elementos sobre tal realidade e também me permitiram problematizar questóes centrais sobre a desinstitucionalização.

No Brasil, conforme o Levantamento Nacional de Crianças e Adolescentes em Serviços de Acolhimento, ${ }^{6}$ o número de serviços de acolhimento chegou a 2.624 em 2010, o que representava 36.929 crianças e adolescentes acolhidos. Desses, 61\% mantinham vínculo com seus familiares. No entanto, ao mesmo tempo que essas estatísticas denotam uma possibilidade ampliada de reinserção familiar, os índices relacionados com o tempo de institucionalização tornam a situação um pouco ambígua, já que o tempo máximo de acolhimento variou de dezesseis meses (no Norte do país) a dezessete anos (no Sudeste) e somente $37 \%$ dos serviços tinham a preocupação de desenvolver açóes de preparação gradativa para o desligamento institucional. Tal realidade reflete igualmente as dificuldades enfrentadas pelas instituições de acolhimento para cumprir orientaçóes do ECA (art. 101), sobretudo no que se refere ao caráter de provisoriedade (no máximo dois anos) e excepcionalidade do processo de abrigamento (Brasil, 1990). Reflete ainda a presença de uma espécie de "cultura 
da institucionalização", que parece acompanhar a história das políticas de assistência à infância (Rizzini e Rizzini, 2004, p. 14).

Nesse ponto é importante esclarecer que, conforme as orientaçóes do ECA, em especial o art. 98 (Brasil, 1990), o acolhimento institucional e familiar é considerado uma medida de proteção e, como tal, poderá ser aplicada quando crianças e adolescentes estiverem em situação de violação de direitos (por omissão da sociedade ou do Estado), por falta, omissão ou abuso dos pais ou responsável e em razão de sua conduta. Atualmente, o afastamento da convivência familiar em função do acolhimento só pode ser determinado por decisão da Justiça da Infância e da Juventude, tendo como orientação prioritária o interesse superior da criança e do adolescente (Silva, 2004). Se, de um lado, assiste-se a um movimento intensivo em favor da convivência familiar e comunitária - legislaçôes, fóruns de debates, reordenamento institucional e redação do Plano de Convivência Familiar e Comunitária (PNCFC) (Brasil, 2006) -, de outro, é possível observar a multiplicação do número de serviços de acolhimento no país.

As experiências dos jovens que completam dezoito anos no âmbito dos serviços de acolhimento ou que estão próximos da maioridade se tornam objeto privilegiado na problematização dos paradoxos postos pelas políticas de proteção. Durante todo o período em que estiveram acolhidos, sob medida protetiva, vivenciaram tal percurso sob as diretrizes do ECA. Isso significa que, formalmente, com a maioridade o ciclo da garantia dos direitos está completo e cumprido. Como observa Gregori (2000), a maioridade, como demarcação de idade, procura estabelecer uma linha que separa a cidadania plena de uma cidadania assistida. Ao romper essa linha, portanto, os jovens não são mais objeto do ECA - a menos em casos excepcionais de pessoas entre dezoito e 21 anos - e, na perspectiva da lei e dos direitos, estariam idealmente prontos, num processo de obtenção da cidadania plena. "Plena" ou "assistida", a cidadania desses jovens fica prestes a se desfazer do lugar específico que o ECA havia produzido e assumir um outro, mais geral e ambíguo, no âmbito da Política Nacional de Assistência Social (PNAS), cuja gestão e operacionalização depende do ainda jovem Sistema Único de Assis- tência Social (Suas) (Brasil, 2005). Desse momento em diante, a maneira pela qual eles serão assistidos e mesmo "classificados" pelas políticas assistenciais depende muito do que farão após o desacolhimento: se vão constituir família, ter filhos etc.

A desinstitucionalização, ao mesmo tempo que constitui uma espécie de não lugar dos egressos nas políticas assistenciais - visto que no Brasil não há nenhuma política social específica voltada para esses sujeitos -, também aponta para a emergência de iniciativas mais "alternativas" que procuram dar continuidade ao trabalho desenvolvido nos serviços de acolhimento. Dentre elas, figuram as chamadas repúblicas, as quais correspondem a uma "modalidade de acolhimento institucional que visa à transição da vida institucional para a vida autônoma, quando atingida a maioridade, sem contar necessariamente com características de ambiente familiar", conforme o glossário do PNCFC (Brasil, 2006, p. 129). $\mathrm{Na}$ impossibilidade de implementar a experiência da república, iniciativas ainda mais alternativas são criadas ou, melhor dizendo, alimentadas às avessas pelo próprio sistema de proteção. É o caso da Casa de Semiliberdade Frutos do Aroeira/Centro Cultural Escrava Anastácia (CCEA), em Florianópolis, que foi concebida para acolher adolescentes e jovens, de ambos os sexos, em cumprimento de medida socioeducativa. ${ }^{7}$ Contudo, em função do aumento da demanda nos serviços de acolhimento e da falta de opçóes para os jovens que nesses espaços permanecem até a maioridade, entre 2012 e 2013 o Frutos também atendeu jovens que haviam sido acolhidos anteriormente por medida de proteção.

Diante desse cenário, seria possível analisar as experiências de desinstitucionalização das oito jovens a partir das lacunas deixadas pelas políticas de proteção à infância e à adolescência após o desligamento institucional. ${ }^{8}$ Nessa perspectiva, o foco analítico recairia sobre as táticas que empreendem para driblar as dificuldades impostas pelo desacolhimento, sobretudo, quando atingem a maioridade. No entanto, por mais que as experiências de desinstitucionalização dessas jovens sejam marcadas por "uma espécie de improvisação contínua", tal dinâmica parece querer dizer mais do que uma simples "estratégia de sobrevivência" em meio a um contexto de instabilidade. 
Nesse sentido é que eu gostaria de propor, neste artigo, uma outra chave analítica, que permite compreender as práticas dessas jovens não apenas como uma resposta/reação às lacunas deixadas pelas políticas de proteção, mas também como possibilidade de inventar constantemente a vida, mesmo em situações e condiçóes em que tal emergência pareceria impossível. Mais do que reiterar a ideia de que essas jovens não ficam esperando por tais políticas e que, portanto, se mobilizam para construir sua própria inserção, busquei pensar as experiências dessas jovens, com base na concepção de invenção de Roy Wagner (2010). Importante mencionar que essa escolha teórica buscou conferir um caráter de experimentação à pesquisa realizada e também revelar outras dimensóes das experiências das jovens “egressas". Seguindo tal perspectiva, pretendo mostrar como o material etnográfico, mais especificamente os relatos das experiências de duas jovens "egressas" (Virgínia e Clarissa), permite pensar nas seguintes vias para a invenção: com base nas experiências da Clarissa, destaco a relação com as políticas assistenciais (sobretudo a busca por direitos no cuidado com os filhos) e a descoberta do que ela sabe e gosta de fazer; no caso da Virgínia, ressalto o cuidado com os filhos e as maneiras de subverter os modos de ação das políticas assistenciais e de saúde.

\section{A “invenção" como chave analítica}

Em uma primeira tentativa de análise das experiências das jovens "egressas", a concepção de táticas, tomadas em seu sentido mais "tradicional" (como maneira de driblar as adversidades), parecia produtiva. No campo da proteção à infância e à adolescência, a pesquisa antropológica realizada por Fonseca, Allebrandt e Ahlert (2009) mostrava que os "egressos" não ficavam esperando passivamente a resolução dos seus problemas, uma vez que procuravam tecer "táticas criativas" para "se darem bem fora do abrigo". Essas táticas, segundo as autoras, ora poderiam ser complementares às lacunas deixadas pelas políticas públicas, ora poderiam burlar aquelas julgadas inoperantes.

Num registro muito próximo a esse das táticas e estratégias, também seria importante destacar a noção de "viração", que ganhou espaço na antropologia a partir da etnografia realizada por Maria Filomena Gregori (anos de 1990) a respeito das experiências travadas pelos meninos de rua. Tomada do linguajar coloquial, a viração - a prática de "se virar" para sobreviver - seria, do ponto de vista da autora, uma "noção exemplar" para descrever tais experiências. Considerando seu caráter dúplice (estratégia de sobrevivência material e mediadora de posicionamentos simbólicos), a viração representa para os meninos de rua mais do que a mera sobrevivência, "embora seja seu instrumento".

As duas perspectivas (táticas e viração), ainda que com suas particularidades, contribuíram para explicar e, sobretudo, visibilizar o potencial de agência de sujeitos ("egressos" e meninos de rua) que, até então, eram tomados como uma "população deslocada ou fadada ao insucesso" (Gregori, 2000). No entanto, ambas as perspectivas pareciam impor algumas limitaçóes para pensar as experiências das jovens que participaram da minha pesquisa. Foi justamente com base na revisão teórica e da análise do material advindo da etnografia que o conceito de invenção proposto por Roy Wagner (2010) emergiu como uma chave analítica potente para pensar as experiências das jovens "egressas". Mas, antes de apresentar como a chave analítica pode "funcionar", é importante uma maior familiarização com a terminologia wagneriana. Um primeiro ponto refere-se à compreensão de que a invenção, diferentemente da perspectiva das táticas e estratégias, não é algo engendrado ou arquitetado previamente, tampouco uma qualidade que permite distinguir os sujeitos e as culturas e categorizar suas açóes. A invenção, nos termos de Wagner, se insere em uma proposta mais ampla e profunda de "análise da motivação humana em nível radical", na qual os interesses (de atores políticos, classes etc.) funcionam apenas como um "fenômeno de superfície" de "questóes fundamentais". Além disso, a invenção não está associada às descobertas acidentais, mas sim a um componente positivo e esperado da vida humana. Logo, os sujeitos são inventivos não exatamente porque elaboram táticas criativas ou atos e ideias originais, ou ainda porque criam pela primeira vez açôes que se tornaram originais. Logo, a própria invenção, nesses termos, depende da for- 
ma como esta é experienciada pelos atores sociais.

Em certo sentido, como propóe Wagner (2010), a invenção não é absolutamente um processo inventivo, mas um processo de "obviação"9 entre os dois domínios reconhecidos da experiência (o reino do inato e o reino do controle humano), que não são necessariamente os mesmos de uma cultura para outra. Toda a invenção precisa envolver tanto um "contexto convencional" quanto um "contexto não convencionalizado", dos quais um "controla” o outro. Cada contexto remete a um modo de simbolização (convencional ou diferenciante) sobre o qual o simbolizador, dependendo da situação ou cultura e sempre de maneira contingencial, concentrará forçosamente sua atenção ou, melhor dizendo, sua ação. Isso significa que toda cultura favorece um tipo de articulação ou combinação entre os dois modos de simbolização e os dois domínios da experiência (inato/artificial). É justamente pela dialética (sem síntese) entre os dois modos de simbolização, e sobretudo pela "obviação" de um deles numa série infinita de reversóes do tipo "figura/ fundo" que se afetam mutuamente, que se produz a invenção (Wagner, 2010; Strathern, 2011).

Assim, é possível pensar nesse momento, de maneira ainda hipotética, em que, quando o contexto convencional é aquele que serve de controle, espera-se que o foco do ator, em termos de ação e pensamento, dirija-se ao comprometimento com algum tipo de convenção cultural (e moral) ideal ou uma expectativa coletiva quanto ao modo como as coisas "devem ser feitas". Ao concentrar sua ação no modo de simbolização esperado, o ator está seguindo as regras ou tentando ser moral. "Isto é, ele controla seu ato de acordo com um tipo de modelo que significa a 'conjunçáo' de sociedade e moralidade, construindo consistência e coesão social" (Wagner, 2010, pp. 88-89). Por outro lado, é possível considerar igualmente a possibilidade de o contexto de controle da ação náo ser o convencionalizado. Nesse caso, o ator organiza sua ação, de maneira a diferir em alguns ou muitos aspectos das convençóes correspondentes às expectativas sociais (e morais).

Em vez de coletivizar o individual e o particular, o ator está particularizando e diferenciando o coletivo e o convencional. Ele está "fazendo as coisas do seu próprio jeito”, seguindo um curso particular de ação em uma situação (isto é, as convençóes compartilhadas da sociedade) que admite cursos alternativos e, assim, tornando aquilo que faz distintivo e individual. Em vez de "seguir as regras" e dirigir seu foco para a consistência e a coesão, ele está deliberadamente "testando" e "estendendo" as "regras", por meio da construção de um mundo de situaçôes e particularidades às quais elas se aplicam (Wagner, 2010, p. 91).

O próprio Wagner (2010, p. 240) sugere que o "contraste entre os dois domínios - o do inato e o do controle humano - pode ser reimaginado de várias formas", ou seja, é possível pensar a configuração de tais domínios para além da relação entre sociedades ocidentais e "tradicionais", como o autor argumenta na introdução da obra, por exemplo, nas diferentes classes e grupos sociais. Nesse sentido, parece-me importante esclarecer que, no presente artigo, náo busco simplesmente aplicar o conceito de invenção a um contexto específico, das experiências de jovens egressas de serviços de acolhimento institucional. Se é inspirador pensar que a "obra wagneriana pode ser lida como uma partitura que produz muitas possíveis músicas e musicalidades" (Maluf, 2011, p. 44), é ao mesmo tempo desafiador fugir de uma simples aplicação do conceito de invençâo, sem incorrer nos riscos de, na descrição, permanecer buscando uma espécie de síntese ou ainda sem fazer emergir a "tensão dialética” proposta por Wagner.

Trata-se, portanto, de romper com o descompasso entre o plano teórico e o empírico, que me faria assumir a perspectiva dialética e, em termos operacionais, mantê-la funcionando sob a lógica das táticas em termos "tradicionais". E nesse sentido, ao contrário do que aparece na obra de Wagner (2010) para fins metodológicos, não compararei sociedades diferentes (sociedade ocidental e "tradicional") como forma de "estabilizar provisoriamente a tensão dialética existente". Neste artigo, a comparação será feita no âmbito de uma mesma "cultura", que é a mesma ou próxima à da pesquisadora, exigindo o estranhamento daquilo que é observado. 
Além disso, penso que a problematização da experiência das jovens, sob a perspectiva dialética, oferece um outro ponto de vista acerca da própria proposta de Wagner (2010), uma vez que pode fornecer elementos que desconstruam uma "espécie de homogeneidade" da cultura ocidental em relação às sociedades tradicionais. Ainda que Wagner esclareça que o comparativo em sua obra funciona como recurso metodológico, o modo de simbolização convencional aparece como uma marca da sociedade norte-americana, sem, no entanto, explorar (com igual tom de novidade) a dimensão dialética presente no âmbito desta (faço essa observação como ressalva, pois compreendo não ser exatamente esse o objetivo da obra de Wagner). Nesse aspecto compartilho com Duarte (2012) a preocupação de romper com o "modo unívoco" e "monolítico" que a etnologia e muitos saberes com os quais ela dialoga têm por vezes se referido à cultura ocidental. Tendo em vista que na antropologia, o trabalho etnográfico e o campo de pesquisa conferem legitimidade "às novas invençôes conceituais e teóricas" no campo de conhecimento (por exemplo, a problematização do conceito de sociedade que emergiu das etnografias sobre a Melanésia), é importante pensar no lugar que a antropologia das sociedades complexas pode ocupar, em termos etnográficos, nessa reconfiguração dos saberes antropológicos contemporâneos e da própria "reinvenção da antropologia” (Maluf, 2011).

Tomar os modos de vida como foco analítico faz com que a própria "vida" seja problematizada. Em Wagner, como destaca Tainah Leite (2011, $\mathrm{n} / \mathrm{p}$ ), é a noção de "vida” e não de "social" que ocupa um papel preponderante: é a partir dela que o autor encontra uma via possível para descrever as diferenças entre as culturas e o próprio trabalho dos antropólogos.

"Assim como variedade, vida também é um valor e critério para medir-se tudo o que é legítimo no campo do humano: se alguma valoração diferenciada pudesse ser feita entre as culturas, certamente seria em termos de sua vitalidade, que ganha qualidade de radiância” (Leite, 2011, n/p).
Trata-se, para Wagner, de tomar a vida enquanto "sequência inventiva". É especialmente a fim de avançar nesse "vitalismo" presente na obra de Wagner que me parece produtivo explorar a dimensão da criação contida na "invenção", no âmbito das sociedades complexas, de maneira mais específica junto às jovens "egressas".

Sobre a noção de invenção wagneriana, Goldman (2004, p. 201) observa que ela deve ser entendida "rigorosamente" no sentido estabelecido por Deleuze e Guattari para a noção de criação. Ou seja, a invenção "não consiste nem na imposição de uma forma ativa externa a uma matéria inerte, nem da descoberta de uma pura novidade, nem na fabricação de um produto final a partir de uma matéria-prima qualquer", mas ela é, sim, da "ordem da metamorfose contínua”. Para além da associação com a metamorfose, gostaria de propor, de maneira ainda inicial e experimental, ${ }^{10}$ uma aproximação da invenção wagneriana à concepção de criação em Nietzsche, a qual me parece produtiva para pensar as experiências das jovens que pude observar em campo. Como aponta Goldman (2011), há alguma coisa da obra de Nietzsche que ecoa na obra de Wagner, para além, eu diria, da expressão "cultura demasiado humana” (Wagner, 2010, p. 238). Para Goldman, "experiência", "vida" e "subjetividade" são categorias que estão presentes tanto em Wagner como em Nietzsche. Mesmo numa leitura mais crítica acerca do que Duarte (2012) tem chamado de "pulsão romântica" ou "atual onda romântica", Tainah Leite (2011) observa uma série de referências que permitiriam identificar os "fios de leitura" que teriam constituído a influência romântica na obra de Wagner, dentre as quais estariam aquelas relacionadas com as reflexóes de Nietzsche.

Nietzsche, segundo Rosa Maria Dias (2011, p. 64), se apodera do termo "criação" para designar um tipo de fazer que não se esgota em um único ato, tampouco em inúmeros atos. "Para ele, o ato de criar não é um simples fazer prático que diz respeito ao terreno da utilidade, náo designa apenas um ato particular, mas um ato fora do qual nada existe [...]". Conforme Dias (2011), ao ampliar a noçáo de arte para dar conta dos atos que produzem constantemente a vida, Nietzsche faz uso do termo "criação" para descrever uma nova forma 
de conduta para com o mundo. Criar é, portanto, uma atividade constante, a partir da qual se estáo sempre efetivando novas possibilidades de vida. Nietzsche propóe a "doutrina da vontade criadora", a qual privilegia a atividade e a "transitoriedade da vida”. Nesses termos, a vontade criadora só pode ser pensada com base em uma íntima relação com o tempo, pois esta é a "única via do criador". Esse tempo não é aquele das longas duraçóes, tampouco o das memórias; é o tempo próprio do devir. $\mathrm{O}$ que nos convidaria a pensar náo no que as jovens "egressas" se tornaram, mas naquilo que elas podem vir a ser como sujeito.

Dito isso, seria importante ressaltar alguns aspectos da produtividade da chave analítica da invenção. Um primeiro aspecto se refere à possibilidade de ela romper com o registro da busca pela sobrevivência que com frequência é acionado para falar sobre as experiências dos sujeitos diante da falta de assistência das políticas públicas. No lugar da sobrevivência proponho, a partir dessa chave, recuperar a dimensão da vida como "sequência inventiva”. Esta, lembra Wagner (2010, p. 146), apresenta um caráter particular, uma certa qualidade de radiância que náo tem nenhuma comparaçáo com o "nosso atarefadíssimo mundo da responsabilidade e do desempenho".

Um outro ponto a ser destacado refere-se ao fato de a invenção permitir descrever e falar sobre as experiências das jovens "egressas", em sua "improvisação contínua”, sem correr o risco de exotizá-las. As práticas dessas jovens podem causar a impressão, ou ilusão (nos termos wagnerianos), de que elas fazem algo que as outras pessoas não fazem. Porém, como alerta Wagner (2010), a invenção é um componente positivo e esperado de toda ação humana e não uma exclusividade de determinados sujeitos ou culturas. Além disso, é importante esclarecer que a opção por concentrar esforços analíticos sobre a dimensão da invenção não quer dizer que as jovens sejam inventivas e os outros não. Elas não são apenas inventividade, e mesmo onde parece haver só invenção a convenção é sempre um fator. Suas experiências, em vez de tentar prever e controlar os acontecimentos, procurando inserir as coisas numa relação ordenada e consistente, segundo as prescrições da convenção, são marcadas pelo esforço de desestabilização do convencional (Kelly, 2005). Assim, interessa menos saber o que é inventado (no sentido de caracterizar os modos de vida implicados nessa invenção) do que analisar como as jovens inventam novas possibilidades de vida e o que tomam como objeto da sua invenção.

\section{A “improvisaçáo contínua” como invençáo de novas possibilidades de vida}

As experiências de desinstitucionalização de duas jovens, Clarissa e Virgínia, me parecem centrais para o movimento de desconstrução da relação de causa e efeito entre políticas de proteção (ou a ausência delas) e as práticas engendradas pelos sujeitos na busca pela sobrevivência. Seus relatos, as maneiras como elas se posicionam em determinadas situaçóes e as minhas observaçóes do seu cotidiano me permitem pensar, justamente, que o problema dos "egressos" não está apenas na ausência de políticas voltadas à desinstitucionalização; parecem evidenciar, ainda, os elementos disponíveis para a emergência da vida e da potência em condiçóes nas quais esta apareceria somente como impossibilidade.

"A minha vida dá um best-seller", Clarissa me disse na primeira vez que eu fui até a casa dela, na época, localizada em Palhoça, Santa Catarina. Na ocasiáo, a jovem tinha 27 anos e era possível perceber que, desde cedo, havia aprendido a fazer as coisas do seu jeito. Quando precisou trocar de emprego, logo após a separação do seu atual companheiro, para dedicar mais tempo ao cuidado da filha, logo colocou suas condiçóes para a dona da padaria:

"Infelizmente, eu não posso trabalhar por menos de mil reais. Se eu tiver uma renda abaixo de mil reais eu não consigo sobreviver, porque é difícil. Tu tem um nível de vida, é muito fácil tu subir, tu voltar é difícil". Diante dos argumentos, a dona da padaria titubeia: "não, mas primeiro tenho que ver teu serviço...”.

Mas Clarissa se mantém firme: "Infelizmente, eu não consigo viver com menos de mil reais". A dona da padaria bateu o martelo: "Então tá, podes começar na segunda-feira”. 
No nosso primeiro encontro, ela estava morando com a filha numa casa de madeira, que à primeira vista me pareceu abandonada. As portas e janelas tinham frestas enormes e pela ação do tempo já não fechavam em sua totalidade. Havia muitos buracos nas paredes e também no assoalho, através dos quais era possível enxergar o chão de terra embaixo da casa. Mas Clarissa nem sempre viveu assim. Como ela mesma fez questáo de dizer, já esteve "bem de vida", tinha casa própria e mais de um carro na garagem e foi dona de bar e lanchonete, mas o ex-marido tinha "colocado tudo fora”. Mãe e filha moravam de frente para o terreno onde anteriormente ficava a sua casa de alvenaria. Desta, na ocasião, só restavam alguns escombros, e da história de como tudo se perdeu parece ter ficado a memória e a certeza de que era preciso recomeçar sozinha.

As experiências de desinstitucionalização da Clarissa foram, desde o princípio, marcadas por uma intensa mobilidade. Embora nunca tenha saído dos arredores de Florianópolis, a jovem mudou várias vezes de moradia, de bairro e mesmo de município. Clarissa diz que precisa estar todo o tempo em movimento, que toda a sua família sempre foi "cigana", no sentido de estarem sempre se mudando, e por isso mesmo não foi apenas ela quem "pulou fora do galho", explica sorrindo. Por fim, concluiu o ensino fundamental em Palhoça, onde também fixou sua residência própria. Embora Clarissa nunca tenha ficado sem trabalho, a sua vontade de ser independente por vezes foi tensionada pela experiência precoce da maternidade e pela baixa escolaridade:

“Toda vida correndo atrás da máquina e tentando arrumar serviço que para mim foi muito difícil, porque eu era muito nova, já tinha filho, pouca escolaridade. Quando eu saí da casa-lar, eu saí só com a sexta série, mesmo estudando, eu saí só com a sexta série”.

Ainda muito cedo, Clarissa teve a sua primeira experiência no ramo da alimentação: foi trabalhar como "saladeira" em um restaurante. A princípio, o emprego seria apenas um instrumento para sua sobrevivência, uma vez que ela estava passando por um momento de grandes dificuldades financeiras. Foi preciso inclusive recorrer à ajuda da diretora da casa-lar (onde foi acolhida durante a infância e adolescência), com quem sempre pôde contar, mas mesmo assim o recomeço para a jovem parecia uma tarefa muito complicada. "Ela me ajudou muito, porque eu não tinha roupa, eu não tinha comida. E, na verdade, mesmo com a ajuda dela, eu ainda passei necessidade". No entanto, esse primeiro emprego se revelaria bem mais do que um modo para ela "se virar" em meio às adversidades, uma vez que com essa experiência ela acabou descobrindo do que gostava e sabia fazer bem. Tanto que essa seria apenas a primeira experiência de muitas outras no ramo da alimentação, bar e lanchonete, tanto sozinha como com o seu atual companheiro.

Em todos os estabelecimentos que Clarissa e o seu companheiro estiveram, a comida e os lanches sempre ficaram sob a responsabilidade e a habilidade da jovem. "Modéstia à parte, eu sou boa na cozinha, a vida me ensinou [...]. Tive que apanhar bastante da vida para aprender, mas aprendi”, relata a jovem, ao se lembrar de todas as dificuldades pelas quais passou para encontrar algo que viria a assumir um lugar em sua vida que extrapola a simples busca pela sobrevivência. Isso fica ainda mais evidente quando a jovem relata as suas experiências durante o período em que esteve separada do seu atual companheiro. Logo que encerrou as atividades da lanchonete que os dois tinham juntos, a jovem chegou a ficar um período sem trabalhar, mas foi justamente o gosto pelo negócio no ramo da alimentação que a fez abrir, na sequência, um pequeno bar em sua casa. "Então, é o meu ramo, é o que eu gosto de fazer”, completa.

Por causa de seu prazer em produzir os lanches e as refeiçóes, havia, além do gosto pela alimentação, outra motivaçâo para a invenção de Clarissa: a vontade de ser autônoma. Quando eu a visitei pela primeira vez, ela estava cumprindo seus últimos meses de trabalho na padaria, onde havia dito que não poderia permanecer por menos de mil reais. $\mathrm{O}$ trabalho na padaria lhe rendia um bom salário e a dona do estabelecimento tinha muita confiança nela. "Na época das vacas gordas", Clarissa lembra, chegou a ganhar 1.800 reais, pois a padaria de fato era bem movimentada e a dona a considerava o seu 
braço direito. No entanto, ela havia tomado a decisão de pedir demissáo desse emprego, justamente porque desejava retomar a ideia de ser autônoma, de ter o seu próprio negócio novamente.

"A dona da padaria está abrindo uma filial na semana que vem, mas eu tô pulando fora, porque é muito bom trabalhar enquanto tá vindo dinheiro, tá girando, só que eu me programei, eu sou autônoma há dez anos, então, eu já vinha me programando".

Ela estava com planos de abrir uma empresa de fornecimento de marmitas em sociedade com um vizinho do seu companheiro. E essa atitude da jovem diante da vida me parece fortalecer ainda mais o argumento de que não se trata de uma questão de sobrevivência, mas de uma vida que valesse a pena ser vivida. Do contrário, por que ela abandonaria o emprego onde já tinha a confiança da dona para investir numa vida de autônoma? Diferentemente do que se poderia imaginar, ser autônoma não lhe causava insegurança, pois, como ela mesma disse, para isso ela "sempre teve peito". Isso porque todo o investimento passa pelo reconhecimento de que é preciso trabalhar em várias frentes para não depender apenas da empresa que ainda estava começando. Pude observar isso no dia em que a jovem recebeu a visita do vendedor de lingeries, com quem ela pegava produtos em consignação para revender e complementar sua renda familiar. Na verdade, ela estava devolvendo os produtos, porque tinha medo de que entrassem na casa e os roubassem, uma vez que a casa onde estava morando não oferecia a menor segurança. $\mathrm{O}$ vendedor, no entanto, procurou se certificar várias vezes da decisão que a jovem estava tomando, já que a Clarissa era uma das melhores, se não sua melhor vendedora. Mas ela tinha uma explicação para a sua decisão naquele momento:

Mesmo porque, assim, eu vendo, eu trabalho com tudo. Eu tô parada um pouco da lingerie porque... vê a insegurança dessa casa. $\mathrm{O}$ outro eu já entreguei, porque eu trabalhava para dois vendedores. Aí eu disse para ele: "Deixa eu me estabilizar, arrumar uma casa decente, que eu volto a pegar”. Eu vendo Natura, eu vendo
Avon. O que aparecer, que eu puder estar ganhando em cima, não me prejudicando, eu tô dentro. Então, eu não vou depender só disso [empresa de marmitas], e uma coisa que vai me ajudar muito é o seguro desemprego.

$\mathrm{Na}$ futura empresa de fornecimento de marmitas, Clarissa entraria com a maior parte do serviço, enquanto o sócio entraria com o dinheiro e com os cuidados da parte administrativa. De maneira muito detalhada, ela já sabia tudo o que precisaria organizar para a empresa começar a funcionar: estrutura física, funcionários, cuidados com os alimentos, ponto comercial para o negócio etc. Ela tinha toda a arquitetura da empresa na sua cabeça e me fazia pensar que ter uma empresa náo era táo complicado como podia parecer. Clarissa estava muito motivada com a possibilidade de ter o seu próprio negócio novamente, ela estava com vontade de trabalhar (pois para ela o trabalho é um valor e o principal objeto da sua invenção dos seus modos de vida), ao passo que o seu sócio estava mais interessado em ganhar dinheiro. Mas mesmo essa incompatibilidade nos planos dos dois não lhe parecia um obstáculo, uma vez que ela tinha clara a divisão de tarefas na condução da empresa. "Mas a questão, assim, ó, a parte dele vai ser vendas, compra e contábil, pois ele é contador e de família de contadores. A minha parte vai ser organização de funcionários". Diante de toda essa programação e do próprio investimento da jovem para que a empresa desse certo, eu podia pensar que, para ela, tal experiência se constituiria como um projeto que daquele ponto em diante mudaria, de alguma maneira, a sua vida.

A princípio, seria possível pensar que ela estava agindo segundo as expectativas da convenção, imprimindo uma lógica de continuidade, estabilidade e coerência às suas experiências. Ela estava criando condiçóes para poder chegar onde havia sonhado, buscando um desfecho para um investimento feito. No entanto - e isso só depois eu viria a compreender -, caso ela náo realizasse esse "projeto" da maneira como havia imaginado, isso não seria tomado como um fracasso, mas como uma possibilidade de criar outras experiências que partissem daquela. Ao que me parece, tal postura só é possível porque suas açóes, em vez de serem orientadas por uma lógi- 
ca temporal baseada na linearidade/continuidade e em uma sucessão de eventos (chronos), são balizadas pela mudança, sobretudo pela maneira como esta aciona seu potencial de agência. Essa relação com o tempo pode ser observada na maneira como a jovem reagiu diante da sua constatação de que a sociedade com o amigo do seu companheiro não valeria a pena, uma vez que o sócio "não era chegado em trabalho" e, por conta disso, ela teria de trabalhar sozinha com o compromisso de dividir os lucros. Ela não só percebeu que, caso desejasse levar adiante a ideia da empresa, precisaria fazer isso sozinha, como também decidiu, em poucos meses, que abriria uma lanchonete, de onde viria o capital para, depois, dar início à empresa de marmitas. Quando me deu essa notícia, ela já estava cumprindo o último mês de trabalho na padaria e havia conseguido o ponto para o seu mais novo negócio.

Mas, diferentemente do que eu imaginara, Clarissa ainda não havia conseguido alugar uma casa onde pudesse morar e instalar a lanchonete. $\mathrm{O}$ ponto também não era exatamente como ela havia planejado. No entanto, o estabelecimento já tinha um nome, e algumas vantagens, tais como a estrutura própria para o seu funcionamento. Essa maneira de a jovem lidar com a mudança e a instabilidade poderia aparecer como ausência de projeto ou mesmo como um não investimento em algo que é esperado pelas convençóes. Isso porque, se aquilo que se espera dos sujeitos é um investimento para controlar a dimensão da invenção (cujo principal componente é a mudança), para que a convenção possa ser mantida/preservada, Clarissa de certa forma estaria subvertendo essa dinâmica.

Porém, é importante questionar o que se deixaria de ver nessa experiência da Clarissa, caso se optasse, numa espécie de "vício cartográfico", por concentrar a análise apenas no lugar aonde a jovem desejaria chegar e não no movimento (invenção) empreendido (com todos os seus desvios e imprevisibilidades) para buscar outras possibilidades. É possível pensar que, ao fazer tal escolha, eu estaria "desdenhando o meio" em que, como afirma Pelbart (2010), se atinge a maior velocidade. Estaria incorrendo numa "falsa concepção da viagem" e do próprio movimento da jovem, pois o "meio" (não uma média) é justamente o lugar do devir. "Esse meio é justamente onde os mais diferentes tempos comunicam e se cruzam num turbilhão" (Idem, p. 113).

$\mathrm{Na}$ tentativa de compreender o que se passa no "meio" é que tento pensar que, ao contrário de tentar prever e mesmo controlar a dimensão diferenciante (procurando criar e manter projetos organizados e bem sucedidos), ela estaria justamente precipitando-a a partir da convenção, daquilo que é esperado. A Clarissa estaria fazendo as coisas do seu jeito, sobretudo no que se refere à questáo da temporalidade. Tanto que ela sabia o tempo exato para esperar que a lanchonete começasse a dar lucro: dois meses. Um tempo curto para alguém interessado em projetos, mas o bastante para fazê-la começar a "caminhar para trás"; para fazê-la perceber que o ponto não estava dando dinheiro e que era preciso buscar outro lugar o mais rápido possível. Tão logo isso aconteceu, em questáo de uma semana ela já estava instalada novamente em outro lugar.

As experiências de desinstitucionalização da Clarissa, como foi possível observar, são marcadas por mudanças de diferentes ordens, que poderiam demandar por parte da jovem uma postura simplesmente reativa, ou de "viração". No entanto, parece-me produtivo supor tais mudanças como motivadoras da invenção de novos modos de vida. As experiências da Clarissa também ajudam a analisar os modos de agir diante das convençóes, sobretudo da possibilidade de desmarcá-las, fazendo emergir um potencial de agência. Em geral, somos acostumados com o esforço para evitar as mudanças, em especial aquelas relacionadas com projetos. A princípio, esse esforço parece bem maior do que aquele feito pelos sujeitos que "assumem" a mudança, mas que não aparentam controlá-la. O caso da Clarissa permite tensionar pressupostos como estes que levariam a tomar a "improvisação" que marca a vida dessas jovens como "estratégia de sobrevivência". Também permite visibilizar o investimento feito por parte dos sujeitos, quando os seus modos de vida vão sendo construídos em função da mudança.

Considero interessante ressaltar que essa "atitude geral" e o "modo de encarar as coisas" da Clarissa foram se delineando mais claramente, nas minhas observaçôes, a partir do contraponto que pude estabelecer com as experiências de outra jovem: Virgínia. ${ }^{11}$ Clarissa e Virgínia se conheceram durante o 
período de acolhimento institucional. Clarissa havia descoberto que a amiga de infância também estava morando na Palhoça e me sugeriu que as duas estivessem juntas nas próximas visitas. Assim, segundo a jovem, poderiam compartilhar suas experiências de desinstitucionalização comigo. Virgínia estava morando no bairro Frei Damiâo, lugar que, segundo o relato da Clarissa, apareceu na mídia em 2010 por conta dos treinamentos do exército para a missão no Haiti. O local foi escolhido em função das suas semelhanças com o país antes e depois do terremoto. $\mathrm{Na}$ ocasião, os moradores mais engajados deram depoimentos acerca do descaso com que eram tratados pelo poder público. Eles relatavam que, mesmo pagando impostos como todos os outros cidadãos, não tinham saneamento, iluminação, fora os graves estados de alagamento com que a comunidade convive frequentemente.

Virgínia tinha 28 anos e teve o primeiro filho com dezessete. No total são oito filhos: sete dela com o seu companheiro e um apenas dele, fruto de uma relação anterior. Pelo fato de não ter com quem deixá-los, a jovem raramente sai de casa. A única visita que recebe é da mãe, e muito raramente vai até a casa da irmã. "Não vou na casa de ninguém e ninguém vem na minha casa. A única que vem volta e meia na minha casa é uma comadre minha”, ela me explicou, revelando um misto de decisão e resignação acerca da sua rotina. Isso não a entristece, pois, como ela mesma diz, sorrindo, "os filhos me alegram”. Além da experiência de diarista, Virgínia, como Clarissa, também vendia perfumes ou lingeries para complementar a renda familiar. Mas com o tempo e as seguidas gestaçôes acabou abandonando todas as atividades que exigissem sua saída de casa. Se existem projetos para o futuro, estes se concentram totalmente na criação dos seus filhos. A jovem conta que não fez a cirurgia de ligadura de trompas porque "tem medo dessas coisas" e que "não toma comprimido" (anticoncepcional) porque "tem problema no coração". Além disso, o fato de ter muitos filhos, como explica a jovem, sorrindo, deve ter uma explicação genética, pois sua mãe e suas irmás seguiram o mesmo caminho: a máe teve dez filhos e a irmã, oito.

Há uma série de elementos presentes no cotidiano da Virgínia que parecem compor, a princípio, um contexto de precariedade das suas condiçóes de vida. Do ponto de vista das políticas, seria possível pensar que a jovem não teria um "projeto de vida" organizado, ou que ela "não teria dado certo". Mesmo tendo sete filhos e em situação de baixa renda, ela explica que só mais recentemente passou a receber o Bolsa Família. No entanto, não foi ela quem foi atrás do benefício, mas a sua mãe: "nunca pedi nada para ninguém", argumenta ela. Essa posição da jovem diante das políticas assistenciais, sobretudo em termos de avaliação do quanto e em que condiçóes precisa de ajuda, é interessante na medida em que revela uma das maneiras pelas quais ela se constitui como sujeito, sem partir, ao contrário do que se poderia imaginar, da falta e da precariedade. Embora tenha uma rede de ajuda restrita, a jovem não se vê numa situação de dificuldades para sustentar todos os filhos. Nesse ponto, já é possível colocar em xeque a questão da sobrevivência em relação à ausência ou dificuldade de acesso às políticas assistenciais. As políticas se fazem presentes, mas a jovem, além de não as tomar como incontornáveis no seu cotidiano, frequentemente não se deixa capturar pelos controles biopolíticos que as acompanham.

Ao longo da etnografia, comecei a observá-la de outro ponto de vista. $\mathrm{O}$ fato de ela estar na gestação do sétimo filho sem nunca ter feito pré-natal, nem procurado ajuda médica em todas as suas últimas gestaçôes, significava outra coisa para além de passividade, negligência e falta de informação. Ao agir dessa maneira, ela estaria driblando (do seu modo) uma rede de controles biopolíticos que se instauram especialmente sobre as populaçóes mais pobres, desde a gestação dos filhos, como ela mesma pôde constatar:

"Os meus outros filhos eu só fui para o hospital no dia de ganhar; senão, eles começam a pedir um monte de exames, tem que estar saindo de casa toda hora. Só agora fiquei sabendo que o meu problema [cardiopatia congênita] é grave”.

Mas é importante ter em vista que onde parece haver apenas vulnerabilidade e pobreza, para ela haveria possibilidade - em especial quando comparada com outras pessoas que, segundo ela, estariam em "pior" situação. Isso pode ser observado no seu 
relato sobre o período em que esteve no hospital para seu sétimo parto. A jovem passou a primeira noite no hospital sentada numa cadeira, por falta de leito. Somente na segunda noite é que a passaram para uma poltrona mais confortável. Embora estivesse grávida e com problema cardíaco, ela sentiu vergonha de reclamar daquela situação, como ela mesma reflete: "Eu vi tanta gente em situação pior que a minha. Eu estava na parte onde só tinha gente com problema no coração”. O fato de estar grávida da sétima filha a colocava numa situação privilegiada em relação àqueles que estavam ali hospitalizados apenas por motivo de doença. Enquanto relata essa situação, ela retira uma maçã de dentro da bolsa, e lembra que a maçã lhe foi dada também no hospital: "Eu não sei o que pensam, só porque a gente tem sete filhos, que, sei lá, que a gente passa fome", diz, sorrindo da situação de desconforto vivenciada durante a hospitalização. Ter sete filhos não era, para ela, motivo de vergonha ou preocupação, era sinal de que ela estava fazendo o seu melhor, como mãe e mulher.

Para Virgínia, o cuidado com os filhos e a maternidade ${ }^{12}$ passam por um lugar que não é exatamente o do conhecimento das políticas públicas e da consequente vigilância em relação à sua execução. Trata-se de uma outra maneira de lidar com essas questóes que, no entanto, náo pode ser desconsiderada e tampouco diminuída, sobretudo quando equiparada com a experiência da Clarissa e de seu modo de conduzir o cuidado com os filhos. A relação entre as experiências de cuidado com os filhos das duas jovens é interessante não pela oposição que, a princípio, parece revelar, mas porque elas nos informam os lugares (valores, condições, afetos) por onde passa tal cuidado e o acento que cada uma lhe confere em cada situação. O mais importante é como cada jovem se vê nas situaçóes em que os filhos lhes demandam cuidado e proteção.

O cuidado, para Virgínia, não passa necessariamente pela garantia dos direitos; no entanto, o cuidado que ela tem com os filhos não é passível de comparação, de substituição: ele é exclusivo, só ela sabe ser mãe daquele jeito, ninguém cuida melhor do que ela. Quando fui visitar a jovem depois de um mês do nascimento da filha, logo que entrei na casa avistei todas as crianças, menos a recém-nascida. A
Clarissa também havia sentido falta da menina, não exatamente nesses termos, e por isso perguntou se a Virgínia havia dado a filha. Ela respondeu que não e explicou que a filha estava na vizinha da casa em frente à sua. A vizinha tinha catorze anos e, segundo Virgínia, passava praticamente todos os dias com a menina: alimentava, dava roupas, trocava as fraldas e a levava para passear. Num primeiro momento, pareceu que a situação havia se tornado confortável para a jovem, que tinha ainda outros três filhos pequenos que ficavam com ela em casa o dia inteiro. No entanto, ela revelou que não gostava que a filha fosse para a casa da vizinha, preferindo que a recém-nascida ficasse em casa sob os seus cuidados. Sorrindo, ela declarou que "filho ninguém cuida como a gente".

Se é assim, o cuidado com os filhos precisa ser em tempo integral e não parece combinar com o trabalho fora de casa. Tanto que Virgínia se preocupava em marcar a diferença entre o seu cuidado com os filhos e o das vizinhas. Por isso, ao menos na minha presença e na da Clarissa, Virgínia fazia questão de enfatizar a falta de cuidado de algumas mães da vizinhança que trabalhavam fora. "A mãe desse aí não tá nem aí, ela vai trabalhar e deixa o filho com a cunhada, eu acho, nem sei se tem alguém com ele hoje”. Além de não ter alguém para cuidar da criança, ela observou que o menino passava todo o tempo na rua, "às vezes não tem ninguém, mesmo com chuva, ele tá solto na rua”. No entanto, embora Virgínia demarcasse essa diferença, é importante pontuar que os seus filhos também têm o hábito de brincar nas ruas do Frei Damião, mas, de alguma maneira, para ela existia uma diferença, que está, ao que me parece, no fato de ela não sair de dentro de casa.

A experiência de reunir a Clarissa e a Virgínia nas minhas visitas se tornou produtiva, na medida em que pude observar o lugar que cada uma ocupa na relação, ou melhor, a maneira como cada uma pode se construir como sujeito. A Clarissa sempre procurava assumir a posição de quem entende de políticas públicas, de quem corre atrás dos seus direitos, de quem não deixa o tempo passar. Ela busca aproveitar a melhor oportunidade no tempo. Essa posição vai sendo construída na medida em que a Virgínia, aparentemente, nâo deseja marcar posição alguma, a não ser a daquela pessoa que não sabe muito bem 
como funcionam as coisas, porque dificilmente sai de casa. $\mathrm{O}$ próprio fato de não sair de casa, em função dos filhos, é usado como esse marcador de posição: de quem nẫo tem obrigação de saber, pois não está exposto às mudanças que acontecem para além da esfera da casa e do cuidado com os filhos. Ao contrário da Clarissa, a Virgínia não faz projeçóes, a não ser a de que, se existe um problema, alguma possibilidade de solucioná-lo aparecerá ou de que alguém vai lhe ajudar e tudo se resolverá de alguma forma, independentemente do seu grau de esforço. Nesse ponto, é importante pontuar que tal posição, embora possa num primeiro momento apontar para o que se poderia chamar de uma ausência de "projeto de vida", na verdade é reveladora de uma maneira de conceber o tempo na qual as decisóes e as escolhas vão sendo tomadas à medida que as situações se apresentam ao sujeito. $\mathrm{E}$ isso nos fornece pistas sobre um estilo de vida que é conformado a partir de uma temporalidade específica que rompe com uma apreensão mais cronológica do tempo (chronos).

Nas ocasióes em que pude reunir as duas jovens para conversar, Clarissa esforçava-se em dar conselhos à amiga, ao passo que esta não parecia lhe dar muita atenção. Isso porque, para Virgínia, a invenção dos seus modos de vida passa justamente por esse ato de desmarcar as convençóes, driblando a trama de controles biopolíticos que espreitam o seu cotidiano, sobretudo a relação de cuidado que procura estabelecer com os filhos. É possível pensar também que, ao agir dessa forma, a jovem não está apenas procurando se libertar do Estado e das políticas através das quais este pode se manifestar no seu cotidiano, mas especialmente buscando se desprender dos modos de subjetivaçáo que o Estado procura instituir (uma condiçẫo de sujeito assistido e em situação de vulnerabilidade). Ao conduzir sua vida desta maneira, Virgínia busca outros modos de se constituir como sujeito, os quais têm menos a ver com lugares instituídos do que com sua atitude de subverter convençôes. Seria possível pensar, talvez, como sugere Ortega (1999, p. 153), na constituição de uma "subjetividade anárquica", que remete à libertação por parte dos sujeitos em relação ao estado e das formas de subjetivaçáo ligadas a ele.

Acompanhando mais de perto e observando como a Virgínia age em diferentes contextos, cha- ma atençáo o relato da jovem sobre o fato de sua filha recém-nascida estar tomando leite de lata. Imediatamente a Clarissa perguntou para a amiga se ela estava recebendo as latas do posto de saúde. A Virgínia respondeu que náo, argumentando que a lata custa 26 reais e que dura em torno de quinze dias. Entấo, a Clarissa insistiu que a amiga procurasse o posto, pois lá ela poderia pegar o leite gratuitamente. No entanto, a Virgínia escutava os conselhos da Clarissa sem parecer lhe dar muita atenção. Em outra ocasião, Clarissa fez questão de me mostrar um dos Centro de Referência de Assistência Social (Cras) que está localizado muito próximo da casa da amiga: "Esse era um lugar que podia ajudar muito a Virgínia, se ela viesse procurar". Mais adiante, no caminho que nos levava até o terminal de ônibus, ela apontou para a escola que fica bem próxima do Cras e refletiu novamente sobre a condição da Virgínia: "Não é tudo tão difícil como ela faz parecer, as coisas estáo perto dela, basta ela ir atrás". A Clarissa faz essa reflexão tendo em vista as queixas da Virgínia sobre a dificuldade de encontrar vaga para os filhos na creche e também de não ter quem os leve até lá, uma vez que ela cuida das sete crianças praticamente sozinha. Por isso, a Virgínia já havia tomado sua decisão de levar os filhos para a escola a partir dos seis anos; até essa idade eles permaneceriam em casa, e ela também.

Considero interessante ressaltar que essa "atitude geral" e o "modo de encarar as coisas" da Virgínia foram se delineando mais claramente, nas minhas observaçóes, a partir do contraponto que pude estabelecer com as experiências da Clarissa. $\mathrm{Na}$ presença das duas jovens, num olhar mais apressado, chama atenção a grande diferença em termos de uma "atitude geral", num "certo modo de encarar as coisas", ou na maneira de "estar no mundo" das duas jovens (Wagner, 2010). Em princípio, a Clarissa parece mais autônoma, empreendedora e decidida. No inverso dessa atitude se situaria a Virgínia, mais dependente do seu companheiro, raramente saindo de casa devido ao número de filhos e sem grandes ambições em relação ao futuro. Diante dessa relação, comecei a pensar que talvez tivesse investido em excesso na potência desses sujeitos, a qual talvez nem todos tivessem - e mesmo que sim, a teriam em intensidades diferentes. Onde estaria a 
potência de uma jovem com sete filhos que não sabe o que acontece além da porta da sua casa? Até entấo, parecia ser possível visualizar apenas passividade, uma inércia diante da vida. Nesse caso, seria diferente o processo da Clarissa, por ela conhecer os seus direitos desde muito cedo (afinal, foi ela quem pediu para ser abrigada) e, assim, batalhar para que eles sejam respeitados e operacionalizados na vida cotidiana?

É interessante observar como a posição que Virgínia assume na presença de Clarissa, e na minha também, se inverteu, no dia em que ela recebeu a visita da irmã mais nova. Aos poucos, ela começou a nos contar a complicada história de vida da irmá. Seu padrasto, quando saiu de casa, sequestrou a irmã, na época com doze anos. Virgínia explicou que a família o denunciou para a polícia, mas eles não foram encontrados. Apenas depois de um tempo é que encontraram o homem com a menina que, a essas alturas, já tinha um filho e estava grávida outra vez. De repente, Virgínia interrompeu a nossa conversa e se dirigiu à irmâ, com uma série de perguntas: "E o teu marido, que não vale nada? Onde é que vocês estão morando?”. Nesse momento, ela se coloca no lugar de quem sabe das coisas, de quem se informa e de quem reage diante das dificuldades. Virgínia também consegue se ver num outro lugar nessa relação, o lugar de quem cuida e não só de quem precisa ser cuidado, protegido. Isso evidencia o caráter relacional desse processo. Ela consegue até mesmo avaliar a sua própria condição que, no limite, é bem menos grave que a da irmá, como ela mesma analisa: "A gente vê essa situação e não sabe como ajudar, mas sempre que eu ganho alguma coisa dos amigos, eu passo para ela”.

Clarissa também se posiciona em relação à situação da irmã de Virgínia; no entanto, ela demarca esse lugar a partir de um outro registro, que é o dos direitos, assumindo seu comprometimento com a "convenção" e, assim, com a "expectativa coletiva quanto ao modo como as coisas devem ser feitas" (Wagner, 2010, p. 88). Clarissa comenta que:

Esse é um caso que a família precisaria assumir, denunciar esse homem, procurar ajuda. Ela precisava ir para um lugar protegido com as crianças, um abrigo que acolhesse ela com as crianças. Ela tem direitos, ela tem direito à aposentadoria e até a uma casa para viver decentemente com os filhos. Dá para ver que ela cuida dos filhos, não seria o caso de separar ela das crianças, mas ela precisaria de um acompanhamento, de um tratamento.

A partir do contraponto das experiências de Clarissa e Virgínia, é possível observar que não se trata apenas de modos opostos de se colocar no mundo - de um lado, uma maneira ativa e vigilante acerca dos direitos e, de outro, uma postura desinteressada e passiva. Tanto a postura de fazer uso dos direitos como aquela que os negligencia devem ser consideradas como invenção de novas possibilidades de vida. Dependendo do contexto, em especial quando uma está na presença da outra, a ação de cada jovem acaba por contrainventar o seu oposto. Ou seja, na presença da Virgínia, as açóes da Clarissa se concentram no registro da convenção, na maneira como se deve agir em relação à garantia dos direitos e de acesso às políticas públicas; já Virgínia volta suas açóes para um modo não esperado por essas mesmas convençōes. Na relação com Clarissa (e, portanto, de uma maneira contingencial), é possível dizer que, para Virgínia, o contexto que serve de controle para a sua ação é o "não convencionalizado". Logo, a maneira como ela se coloca em relação à questấo dos direitos difere em alguns aspectos das expectativas sociais e morais (representadas nesse caso pela postura da amiga). Isso significa, nos termos wagnerianos, que Virgínia está "fazendo as coisas do seu jeito", tentando tornar sua maneira de agir e de se posicionar como algo "distintivo e individual”. Do seu ponto de vista, ela está recriando e/ ou estendendo um contexto convencionalizado de forma individual, "transformando-o em sua 'vida' ou em 'seu tipo' de vida” (Wagner, 2010, p. 91).

Se na presença da Virgínia a Clarissa concentra sua atenção no modo de simbolização convencionalizante, em outros contextos este é em geral obviado, permanecendo como fundo, a fim de precipitar justamente o seu oposto: o modo de simbolização diferenciante. Isso porque essas são posiçóes que são assumidas de maneira contingencial e que, portanto, podem ser invertidas dependendo do contexto, conforme procurei mostrar na descri- 
ção do encontro das jovens com a irmã da Virgínia. Nesse sentido, seria possível pensar que para Virgínia a invenção de novas possibilidades de vida passa fundamentalmente pelo cuidado com os filhos e pela maneira como subverte os modos de ação das políticas assistenciais, enquanto que para Clarissa essa invenção está intimamente relacionada com o seu trabalho e, sobretudo, com seu desejo de autonomia. É nessa articulação entre trabalho e autonomia que parece emergir sua potência.

\section{Consideraçóes finais}

Mais do que reiterar a ideia de que essas jovens não ficam esperando por tais políticas e que se mobilizam para construir sua própria inserção, busquei pensar os seus modos de vida com base na chave analítica da invenção. E, seguindo tal perspectiva, desde o princípio me pareceu produtivo analisar não quem são as egressas, mas uma parte, ainda que pequena, daquilo que elas podem vir a ser, do devir. Não procurei tipos de existência, tampouco a tipificação dos sujeitos, pois isso esgotaria a própria dimensão criadora que pretendi revelar. Da mesma forma, interessava menos saber o que estava sendo inventado pelas jovens (o produto da invenção, no sentido de caracterizar modos de vida) do que as maneiras pelas quais elas inventam novas possibilidades de vida. Ou, como diria Wagner (2010, p. 195), o que está em pauta nessa discussão é saber "como as pessoas criam suas próprias realidades e como criam a si mesmas e suas sociedades por meio destas, mais do que a questão de saber o que são essas realidades". Isso porque não se travava de tomar como objeto da análise o ponto/lugar aonde essas jovens desejariam chegar - que é inventado. Tal perspectiva faria com que as experiências desses sujeitos fossem tomadas a partir de uma concepção de "projeto de vida" e dos possíveis insucessos e impossibilidades postos pela não efetivação destes. Em vez de ponto de chegada, o foco analítico esteve voltado para o "movimento empreendido" pelas jovens, com todos os seus "desvios" e "recomeços", na busca por novas possibilidades de vida. Para isso, o diálogo com Roy Wagner foi fundamental, uma vez que me permitiu perceber que a invenção tem pou- co a ver com as "táticas" e mesmo com a "viração". A invenção está para além da sobrevivência e não é um ato que demarca a exotização dos sujeitos.

Ao trazer para o primeiro plano da minha análise os modos de vida da Clarissa e da Virgínia, pude perceber que havia dois aspectos fundamentais que atravessavam as suas experiências: a mudança e a temporalidade. Os dois articulados apontam para um modo de inventar novas possibilidades de vida que tem como característica uma espécie de "improvisação contínua”. E esta, como procurei mostrar, em vez de revelar uma postura simplesmente reativa diante das adversidades, estava relacionada com aquilo que "souberam criar". Nesse criar, estão implicados diferentes saberes e experiências, os quais permitiram às jovens descobrir aquilo que elas sabem e gostam de fazer. Tal descoberta se torna a própria "motivação" (nos termos wagnerianos) para a ação (emergência da agência) e para a construção de uma "atitude geral" em relaçáo ao mundo, que, em vez controlar a invenção, a precipita.

Falar sobre agência, como lembra Sherry Ortner (2007), assim como falar sobre sujeito, nos coloca sempre uma série de problemas. Torná-lo foco principal nas reflexôes pode mesmo nos colocar num dilema: vitimização ou romantização. E se a perspectiva da criação/invenção claramente me afastou do risco da vitimização, ela abre muito espaço para ser compreendida a partir de um viés romântico: as jovens que inventam possibilidades de vida onde só parece haver vulnerabilidade, as jovens que enfrentam as dificuldades e não parecem interessadas em controlar a dimensão da invenção, as jovens para as quais a mudança tem mais a ver com vida do que com sobrevivência, as jovens que desmarcam as convençóes e subvertem os controles biopolíticos etc.

Contudo, como procurei mostrar, em diálogo com Wagner, a invenção não é absolutamente um processo inventivo, mas um processo de obviação entre os dois domínios reconhecidos da experiência, numa série infinita do tipo "reversão figurafundo". Cada cultura, cada sujeito, de maneira contingencial, articula tais domínios aos dois modos de simbolização, diferenciante ou convencionalizante. A questão da "contingência" e do aspecto relacional desse processo é fundamental para a compreensão 
da proposta da invenção, como procurei mostrar por vezes, sobretudo, na experiência de reunir a Clarissa e a Virgínia.

As experiências da Virgínia e da Clarissa também permitem revelar alguns aspectos da dimensão vivencial dos sujeitos, ou seja, os seus modos de agir e avaliar o mundo e os seus interlocutores no mundo (Rifiotis, 2014). Ao agirem e se posicionarem de uma determinada forma, ao fazerem suas escolhas, elas se constituem como agentes poderosas da sua própria desinstitucionalização. Assim, com a proposta do resgate da dimensão vivencial dos sujeitos, náo pretendo que as políticas possam contemplar as demandas particulares de cada sujeito, pois toda política pública segue certas categorias universalizadoras. Trata-se de colocar em perspectiva uma concepçáo de universal, como forma de estimular o debate por políticas mais plurais, que não tomem a "falta" (de políticas, de recursos, de formação etc.) como a única possibilidade de os sujeitos serem contemplados. Pensar na pluralidade dessas políticas, inspirada pela reflexão de Amartya Sen acerca da ideia de justiça (2011), significa compreender que elas precisam estar cada vez mais conectadas aos modos como os sujeitos vivem ou a vida que são capazes de levar e não meramente à natureza das instituiçóes que as cercam. É exatamente nesse ponto que reside a produtividade da chave analítica da invenção, na medida em que traz para o primeiro plano da análise a realização criativa desses sujeitos e as diferentes temporalidades contidas em suas experiências.

\section{Notas}

1 Trecho do meu diário de campo, elaborado com citaçóes literais dos relatos da Nina, uma das jovens que participou da pesquisa, e também com as minhas observações. Por questóes éticas, ressalto que todos os depoimentos tiveram sua publicação autorizada para fins acadêmicos e que os nomes das jovens foram trocados, conforme havia sido acordado durante o trabalho de campo.

2 De acordo com a Tipificação Nacional de Serviços Socioassistenciais, os Serviços de Acolhimento Institucional compreendem abrigos institucionais, casas -lares, casas de passagem e residência inclusiva.
3 Durante a realização do trabalho de campo, num primeiro movimento de cunho mais exploratório, eu consegui localizar/encontrar 23 jovens de Santa Catarina (Florianópolis, Palhoça, Mondaí) e do Rio Grande do Sul (Porto Alegre, Ijuí, Sapiranga) que haviam passado pela experiência de acolhimento institucional. Para a realização de uma etapa mais sistemática da pesquisa, envolvendo a observação sistemática desses sujeitos e também a realização de entrevistas em profundidade, selecionei catorze jovens (onze mulheres e três homens). Desse universo, selecionei as oito jovens que deram vida à escrita da minha tese de doutorado. Nesse trabalho de localizaçáo dos sujeitos, não estabeleci recortes prévios como idade, tempo de acolhimento, motivo do desacolhimento, gênero etc. No entanto, é importante esclarecer que não participaram da pesquisa os(as) jovens que após o período de acolhimento foram encaminhados(as) para adoçáo formal, uma vez que tal condição ampliaria o escopo da reflexão.

4 Utilizo aspas na palavra egresso como forma de sinalizar uma série de problemas de ordem teórico-metodológica, uma vez que remete aos jovens como produto da institucionalização. A problematização dessa categoria encontra-se em Cruz (2014).

5 Importante mencionar, no entanto, que o futuro das crianças que passaram pela experiência do acolhimento vem sendo pesquisado por diferentes áreas (sociologia, psicologia e ciências da educação) há mais tempo em outros países, conforme o balanço crítico publicado por Isabelle Frechon e Annick Camille Dumaret em 2008, com base em mais de trinta estudos franceses e estrangeiros sobre a temática. Nos países anglo-saxóes, onde o serviço social é conhecido como disciplina científica, a situação dos ex-placés na idade adulta vem sendo pesquisada desde os anos de 1950. A França, onde por um longo período tal temática suscitou poucas pesquisas, a partir dos anos de 1980 assiste a um investimento, sobretudo por parte do campo acadêmico e das associaçóes, em saber o que se passa com os jovens que deixam os serviços de acolhimento. Eu também pude observar esse interesse ampliado pela questão dos egressos na minha pesquisa de pós-doutorado, realizada na França entre 2015 e 2017, em especial por parte de entidades que investem em um mapeamento detalhado do devenir desses sujeitos. São trabalhos (realizados por demógrafos, sociólogos, psicólogos e administradores) que fornecem amplos mapas descritivos acerca da inserção desses jovens e que, por vezes, levam à avaliação dos projetos educativos implementados pelas associaçóes e mesmo das políticas de proteção à infância e à juventude de maneira mais abrangente. 
6 Uma iniciativa do Ministério do Desenvolvimento Social e Combate à Fome (MDS), executado em parceria com o Centro Latino-Americano de Estudo de Violência e Saúde Jorge Careli (Claves/Fiocruz). O levantamento é conformado por dados referentes ao acolhimento institucional e familiar, por meio do Serviço de Acolhimento Institucional (SAI) e dos Programas de Família Acolhedora (PFAs).

7 Aplicada, conforme disposições do ECA, quando é verificada a prática de ato infracional.

8 No Brasil, não existe nenhuma legislação específica voltada aos "egressos" após a maioridade. Lembrando que apenas a França, a Noruega, a Suécia, a Finlândia, os Estados Unidos e a Inglaterra possuem uma legislação específica em direção aos jovens que deixam o dispositivo de proteção à infância (Oned, 2009).

9 Para Wagner (2011, pp. 974-975), a "obviação", como método, funcionaria como uma espécie de consumação da noção hegeliana de dialética que termina em síntese e, portanto, no fim da dualidade. Wagner prefere assumir a tensão permanente ao propor que, com a obviação, se produz uma síntese e então uma antissíntese. Essa "dialética compulsória", como pontua Wagner, nunca será menos ou mais que uma dialética, visto que contém em si própria a continuidade: "Não importa o aspecto que o ator escolha como controle para suas açôes, não importa se ele coletiva ou diferencia, ele vai contrainventar e 'preparar' o outro aspecto" (Idem).

10 Trata-se de uma tentativa de diálogo presente já na minha tese de doutorado e que trago neste artigo como forma de contribuir para com a proposta de invenção de novas possibilidades de vida. Importante ressaltar que procurei aproximar a invenção, em Wagner, da criaçáo, em Nietzsche, sem a pretensão de ser propriamente uma wagneriana ou nietzschiana. Se num primeiro momento tive receios quanto a essa aproximação, com o tempo, pude descobrir nos próprios autores a liberdade e inspiração para, "reunir as pontas soltas" e inventar a partir das suas obras, tendo como base a etnografia realizada. Seguindo tal perspectiva pretendo desenvolver tal proposta de maneira mais aprofundada em artigos futuros.

11 Ressalto que os relatos etnográficos acerca das experiências da Virgínia apresentados, na sequência, já foram publicados, com objetivos analíticos diferentes, em outras duas revistas. Em uma primeira publicação (Cruz, 2015), com o objetivo de problematizar a maternidade como invenção, tendo em vista como as experiências de maternidade e as práticas de cuidado com os filhos constituíam as maneiras pelas quais as jovens podiam inventar novas possibilidades de vida. A segunda publicação do material etnográfico sobre as experiências da Virgínia (Rifiotis, 2016) buscava pensar a relação entre sujeitos e políticas públicas, a partir da inversão da perspectiva "mais tradicional" acerca dos direitos dos sujeitos.

12 Ao longo da pesquisa, pude observar que a maternidade para a Virgínia se constitui como um "poder insubstituível", como o "ideal da realização feminina". Para a jovem, a posiçáo de sujeito (mulher) se realiza em plenitude em função de outra posição (mãe). Nesse sentido, a jovem corresponde às expectativas sociais (em termos de políticas públicas) de que as duas posiçôes de sujeito (mulher-mãe) sejam a mesma (Meyer, 2005). Do ponto de vista das políticas, ela estaria seguindo as convençóes, mas imediatamente as contrainventa quando, ao tentar escapar dos controles biopolíticos impostos por elas, acaba deixando de acessar os serviços assistenciais e da rede de saúde. Essa reflexão acerca da maternidade como invenção encontra-se desenvolvida em outro artigo (Cruz, 2015).

\section{BIBLIOGRAFIA}

ALTOÉ, Sônia. (2009), Menores em tempo de maioridade: do internato-prisáo à vida social. Rio de Janeiro, Centro Edelstein de Pesquisas Sociais. Disponível em http://books.scielo.org/id/y7btb/pdf/altoe-9788599662953.pdf, consultado em 23/7/2018 [atualizado].

BRASIL. (1990), Lei n. 8.069, de 13 de julho de 1990. Dispóe sobre o Estatuto da Criança e do Adolescente e dá outras providências. Brasília, Diário Oficial da União, Seção 1 (16 jul. 1990): 13563 [retificada no Diário Oficial da União, Seção 1 (27 ago. 1990): 18551].

BRASIL. (2005), Política Nacional de Assistência Social. Brasília, Ministério do Desenvolvimento Social e Combate à Fome/Secretaria Nacional de Assistência Social. Disponível em http:// www.mds.gov.br/webarquivos/publicacao/assistencia_social/Normativas/PNAS2004.pdf, consultado em 23/7/2018.

BRASIL. (2006), Plano Nacional de Convivência Familiar e Comunitária. Brasília, Ministério do Desenvolvimento Social e Combate à Fome/ Secretaria Nacional de Assistência Social. Dis- 
ponível em https://www.mds.gov.br/webarquivos/publicacao/assistencia_social/Cadernos/ Plano_Defesa_CriancasAdolescentes\%20.pdf, consultado em 23/7/2018.

CRUZ, Fernanda. (2014), Jovens em devir: invenção de novas possibilidades de vida para além da institucionalização. Tese de doutorado. Florianópolis, UFSC.

CRUZ, Fernanda. (2015), "Da maternidade como invenção de novas possibilidades de vida: análise das experiências de jovens 'egressas' de serviços de acolhimento institucional". Civitas, 15 (2): 179.

DIAS, Rosa Maria. (2012), "Nietzsche: educador da humanidade". Lampejo, 1 (2): 10-16. Disponível em http://revistalampejo.apoenafilosofia.org/edicoes/edicao-2/artigos/Artigo2_ Rosa_10_a_16.pdf, consultado em 23/7/2018.

DUARTE, Luiz Fernando Dias. (2012), "O paradoxo de Bergson: diferença e holismo na antropologia do Ocidente”. Mana, 18 (3): 417-448.

FIGUEIRÓ, Martha Emanuela Soares da Silva. (2012), Acolhimento institucional: a maioridade e o desligamento. Jundiaí (SP), Paco.

FONSECA, Claudia; ALLEBRANDT, Débora \& AHLERT, Martina. (2009), "Pensando políticas para uma realidade que não deveria existir: 'egressos' dos sistemas de abrigos", in Claudia Fonseca e Patrice Schuch (orgs.), Politicas de proteção à infância: um olhar antropológico, Porto Alegre, Editora da UFRGS.

FONSECA, Claudia; MAGNI, Claudia Turra; PASINI, Elisiane \& PAIM, Eloisa. (2009), "Trajetórias paralelas: uma avaliação de algumas meninas egressas da Febem-RS”, in Claudia Fonseca e Patrice Schuch (orgs.), Politicas de proteção à infância: um olhar antropológico, Porto Alegre, Editora da UFRGS.

FRECHON, Isabelle \& DUMARET, Annick Camille. (2008), “Bilan critique de 50 ans d'études sur le devenir adulte des enfants placés". Neuropsychiatrie de l'Enfance et de l'Adolescence, 56 (3): 117-172.

GOLDMAN, Marcio. (2011), "O fim da antropologia” [online]. Novos Estudos Cebrap, 89: 195211. Disponível em http://www.scielo.br/pdf/ nec/n89/12.pdf, consultado em 23/7/2018.
GREGORI, Maria Filomena. (2000), Viração: experiências de meninos nas ruas. São Paulo, Companhia das Letras.

KELLY, José Antonio. (2005), "Notas para uma teoria do 'virar branco"”. Mana, 11 (1): 201-234. Disponível em http://www.scielo.br/pdf/mana/ v11n1/25696.pdf, consultado em 23/7/2018.

LEITE, Tainah. (2011), Roy Wagner e a pulsão romântica: antropologia e crítica à ideologia moderna em A invenção da cultura [mimeo]. Trabalho apresentado à disciplina Antropologia e Filosofia do Programa de Pós-Graduação em Antropologia Social do Museu Nacional. Rio de Janeiro, UFRJ.

MALUF, Sônia Weidner. (2011), "A antropologia reversa e 'nós': alteridade e diferença'. Ilha - Revista de Antropologia, 12 (1-2): 39-56. Disponível em https://periodicos.ufsc.br/index.php/ ilha/article/view/2175-8034.2010v12n1-2p41, consultado em 23/7/2018.

MEYER, Dagmar E. Estermann. (2005), "A politização contemporânea da maternidade: construindo um argumento". Gênero, 6 (1): 81-104. Disponível em http://www.revistagenero.uff.br/index.php/revistagenero/article/ view/198, consultado em 23/7/2018.

ONED - Observatoire National de L'enfance en Danger. (2009). "Entrer dans l'âge adulte: la préparation et l'accompagnement des jeunes en fin de mesures de protection" [relatório redigido por Pierrine Robin e cols.]. Disponível em www.fondation-enfance.org/wp-content/ uploads/2016/10/onpe_accompagnement_ jeunes_fin_mesure_protection.pdf\&form id=hpo_publication_list_filter_form, consultado em 23/7/2018.

ORTEGA, Francisco. (1999), Amizade e estética da existência em Foucault. Rio de Janeiro, Graal.

ORTNER, Sherry B. (2007), "Poder e projetos: reflexões sobre agência”, in Miriam Pillar Grossi, Cornélia Eckert e Peter Henry Fry (orgs.), Conferências e práticas antropológicas, Blumenau (SC), Nova Letra. Disponível em www. abant.org.br/conteudo/livros/ConferenciaseDialogos.pdf, consultado em 23/7/2018.

PELBART, Peter Pál. (2010), O tempo não-reconciliado: imagens de tempo em Deleuze. São Paulo, Perspectiva. 
RIFIOTIS, Fernanda Cruz. (2016), “'Egressos' de serviços de acolhimento institucional e políticas públicas: a 'reversão figura-fundo'”. Revista de Antropologia, 59: 214-238.

RIFIOTIS, Theophilos. (2014), "Judicialização dos direitos humanos, lutas por reconhecimento e políticas públicas no Brasil: configuraçóes de sujeito". Revista de Antropologia, 57 (1): 119-144.

RIZZINI, Irene \& RIZZINI, Irma. (2004), $A$ institucionalização de crianças no Brasil: percurso histórico e desafios do presente. Rio de Janeiro/ São Paulo, Editora PUC-Rio/Loyola.

SEN, Amartya. (2011), A ideia de justiça. São Paulo, Companhia das Letras.

SILVA, Enid Rocha Andrade da (coord.). (2004), $O$ direito à convivência familiar e comunitária: os abrigos para crianças e adolescentes no Brasil. Brasília, Ipea/ Conanda.

STRATHERN, Marilyn. (2011), "Sobre o espaço e a profundidade”. Trad. Priscila da Costa. Cadernos de Campo, 20: 1-360. Disponível em revistas.usp.br/ cadernosdecampo/article/ view/36809, consultado em 23/7/2018.

WAGNER, Roy. (2010), A invenção da cultura. Trad. Marcela Coelho de Souza e Alexandre Morales. São Paulo, Cosac Naify.

WAGNER, Roy. (2011), "O Apache era o meu reverso" [entrevista]. Revista de Antropologia da USP, 54 (2): 919-978. 


\section{“EGRESSAS" DE SERVIÇOS DE ACOLHIMENTO E A INVENÇÁO DE NOVAS POSSIBILIDADES DE VIDA}

\section{Fernanda Cruz Rifiotis}

Palavras-chave: Jovens "egressas"; Invenção; Serviços de acolhimento institucional; Políticas públicas.

$\mathrm{O}$ artigo analisa os modos pelos quais jovens "egressas" de serviços de acolhimento institucional (abrigos, casas-lares) inventam novas possibilidades de vida, sob condiçôes que a princípio reforçariam sua vulnerabilidade e falta de potência. A análise tem como base a etnografia realizada sobre as experiências de desinstitucionalização de jovens de Santa Catarina e do Rio Grande do Sul entre 2010 e 2013. As experiências de desinstitucionalização dessas jovens poderiam ser pensadas a partir das lacunas deixadas pelas políticas de proteção após o desacolhimento. No entanto, por mais que essas experiências sejam marcadas por "uma espécie de improvisação contínua”, tal dinâmica revela mais do que uma simples "tática de sobrevivência”. Assim, a proposta é pensar esses modos de vida com base na chave analítica da invenção (Roy Wagner). Dentre as vias para a invenção, destacam-se o cuidado com os filhos, as maneiras como subvertem os modos de ação das políticas assistenciais e a descoberta do que sabem e gostam de fazer.

\section{YOUNG FEMALE "CARE- LEAVERS” AND THE INVENTION OF NEW LIFE POSSIBILITIES}

\section{Fernanda Cruz Rifiotis}

Keywords: Young female "care-leavers"; Invention; Foster care services; Public policies.

This paper analyzes the ways in which young female "care leavers" (from shelters, foster homes) invent new life possibilities under conditions that,at first, could reinforce their vulnerability and lack of power. The analysis is based on an ethnographicstudy carried out between 2010 and 2013 and focuses on the deinstitutionalization of young women from Santa Catarina and Rio Grande do Sul. These young women'sexperiences of deinstitutionalization could be considered from the perspective of the gaps left by the protection policies after departing from foster care. However, as much as these experiences are marked by "a kind of continuous improvisation," such strategy does reveal more than a simple "survival tactics". Thus, the idea is to reflect upon these ways of lifeunder thelight of the analytical key of "invention", as proposed by Roy Wagner. Among the pathways for invention, we highlight the upbringing of children, the manner with which these young women subvert the dynamics of welfare policies and the discovery of what they know and like to do.

\section{LES « EX-PRIS EN CHARGE» DES SERVICES D'ACCUEIL ET L'INVENTION DE NOUVELLES POSSIBILITÉS DE VIE}

\author{
Fernanda Cruz Rifiotis
}

Mots-clés: Jeunes filles « ex-prises en charge "; Invention; Services de prise en charge institutionnelle; Politiques publiques.

Cet article analyse les façons par lesquelles les jeunes filles « ex-pris en charge "des services d'accueil institutionnels (foyers, foyers d'accueil), inventent de nouvelles possibilités de vie, dans des conditions qui, à principe, renforceraient leur vulnérabilité et leur manque de puissance. L'analyse s'appuie sur l'ethnographie réalisée à partir d'expériences de désinstitutionalisation de jeunes des États de Santa Catarina et de Rio Grande do Sul entre les années 2010 et 2013. Les expériences de la désinstitutionalisation de ces jeunes filles pourraient être considérées à partir des lacunes laissées par les politiques de protection suite à leur renvoi des établissements d'accueil. Néanmoins,malgré le fait que ces expériences soient marquées par "une sorte d'improvisation continue ", cette dynamique révèle plusqu'une simple " tactique de survie ". Ainsi, nous proposons de réfléchir à ces modes de vie à partir de la clé analytique de l'invention (Roy Wagner). Parmi les voies vers l'invention, citons le soin avec leurs enfants, les diverses façonsde renverser les modes d'action des politiques sociales et la découverte de ce qu'elles savent et aiment faire. 